\title{
The Effect of Book Value, Debt to Equity Ratio, Roa, Interest Rate and Exchange Rate at Jakarta Islamic Index (JII)
}

\author{
Heffi Christya Rahayu ${ }^{1 *}$, Etty Puji Lestari ${ }^{2}$, Tri R. Kuniawati ${ }^{2}$ \\ ${ }^{1}$ Universitas Pasir Pangaraian, Riau, Indonesia \\ ${ }^{2}$ Universitas Terbuka, Indonesia \\ *Corresponding author e-mail: heffirahayu@upp.ac.id
}

\begin{tabular}{ll}
\hline Article Info & Abstract \\
Keywords: & The Jakarta Islamic Index (JII) consists of 30 companies whose \\
Market Efficiency; & liquid assets have large capitalization compared to other \\
Sharia Capital Market; & companies. JII then becomes a measure of performance in choosing \\
Share; & a halal stock portfolio. This study aims to determine the factors that \\
Jakarta Islamic Index & affect the company's stock price in JII. This research uses \\
& quantitative methods with the study applied is panel data regression \\
& analysis method. The data used in this study is secondary data \\
DOI: & obtained from Bank Indonesia, the Financial Services Authority, \\
10.33830/elqish.vli1.1570.2021 & the Indonesia Stock Exchange, and other literature. Secondary data \\
& or qualitative data used is panel data from 30 companies in JII. \\
& Findings. This research shows that Book Value, Debt Equity \\
& $\begin{array}{l}\text { Ratio, Return on Assets (ROA), Interest Rate, and Exchange Rate } \\
\text { simultaneously significantly affect the Stock Price. JII consists of }\end{array}$ \\
& 30 companies whose liquid assets have large capitalizations \\
compared to other companies. Market capitalization is an indicator \\
of stock development, if there is a decline in stock prices, the \\
market capitalization will decrease.
\end{tabular}

\section{Introduction}

The economic development of a country cannot be separated from the investment conditions. The more developed a country is, the greater the role of investment. In developed countries, the role of the capital market is bigger than banking institutions in channeling funds to the productive sector. Currently, the development of the capital market continues to follow developments in the existing financial system. One of the reforms is the sharia-based capital market which follows the development of the Islamic financial industry. In Indonesia, the Islamic capital market was opened on July 3, 1997, with the issuance of Islamic mutual fund instruments by PT. Danareksa Investment Management. Furthermore, on July 3, 2000, PT. Danareksa Investment Management published the Jakarta Islamic Index (JII), a capital market that uses the Islamic capital market mechanism. With a majority Muslim population, the Indonesian government uses JII to play its role in the national economy (Oktaviani, 2017).

The purpose of establishing JII is to increase investor confidence and provide benefits for investors in implementing Islamic sharia to invest in the stock exchange. JII is also expected to support the transparency and accountability process of sharia-based shares in Indonesia. In other words, JII becomes a guide for investors who want to invest their funds in Sharia without fear of being mixed with riba funds. In addition, JII is a measure of performance in choosing a halal stock portfolio, because it is following the principles of sharia in Islam (Kurniawan, 2016). JII consists of 30 companies whose liquid assets have a large capitalization compared to other companies. Market capitalization is an indicator of stock development, where if the stock price rises, it will trigger an increase in market capitalization. Likewise, if there is a decline in share prices, market capitalization will decrease (Samsuar \& Akramunnas, 2017). 
The following is a graph of the development of the Jakarta Islamic Index market capitalization.

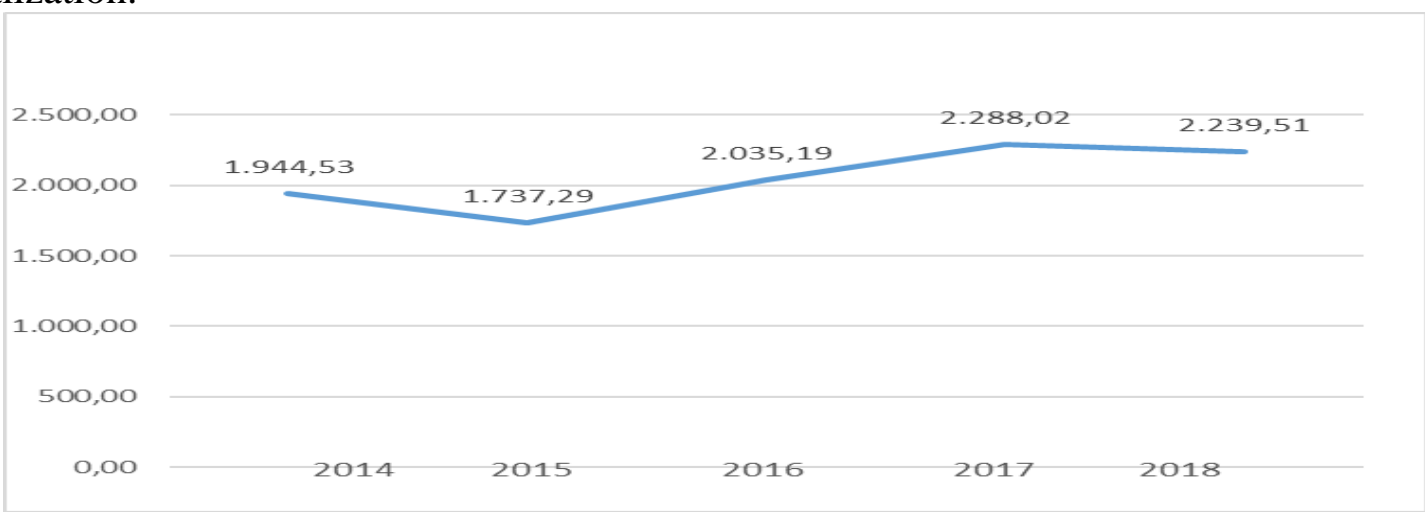

Figure 1. Development of Market Capitalization (JII) 2014-2018 (Trillion Rupiah)

Source: Financial Services Authority (OJK)

Based on the graph of market capitalization in the Jakarta Islamic Index, it has developed quite well but fluctuates, in 2014 the capitalization of shares in JII reached IDR1944 trillion then in 2015 it decreased to IDR 1737 trillion. In 2016, stock capitalization increased by Rp2,035 trillion and again increased in 2017 to Rp2,288 trillion. However, in 2018 the capitalization experienced an insignificant decrease to Rp2,239 trillion. Looking at the development of market capitalization illustrates that there has been a decline and increase in company shares in JII. The development of JII shares can be influenced by various factors, both internal factors from the company and external factors originating from the condition of the Indonesian economy.

Stock price from literature is influenced by book value, DER, ROA, interest rates, and exchange rates. Book value per share shows the net assets (net assets) owned by shareholders by owning per share. Because net assets are equal to total shareholder equity, the book value per share is total equity divided by the number of shares outstanding (Hantono et al., 2019). The book value of each share is calculated from the total book value divided by the number of shares (Sunariyah, 2011).

Another variable like debt to equity ratio (DER) is used to measure the level of leverage (use of debt) to the total equity owned by the company. A high debt ratio has a bad impact on the company's performance, because the higher the debt level, which means the interest expense will be greater so that it can reduce profits. On the other hand, a small debt ratio indicates better performance, because it causes a higher rate of return (Muksal, 2016). The greater the DER, the lower the company's stock price because the company has to pay debts and investors are increasingly unattractive to buy company shares (Samsuar \& Akramunnas, 2017).

Return on Assets (ROA) is a ratio that measures the company's ability to generate net income based on certain asset levels. Return on assets (ROA) measures how well management uses all assets to generate profits or profits. Therefore, the greater the company's ROA, the greater the level of profit achieved by the company (Rahman \& Suherman, 2017). Return on assets is one of the profitability ratios, ROA is also a measure of income or profit for the owners of the capital that has been used by the company.

One of the factors that affect stock prices is the company's ability to pay dividends. If dividends are paid high, the stock price will also tend to be high and the value of the company will be high. The company's ability to pay dividends related to ROA acts as an indicator of the company's efficiency in using assets to earn profits (Z. Hasanah et al., 2017). According to Prastowo, (2008) interest rates can be defined as the rate of return on assets that have a risk close to zero. An increase in interest rates makes the yield on deposits and bonds more attractive so that 
many capital market investors shift their stock portfolios. According to Mankiw (2006), the exchange rate is the price level agreed by residents of the two countries to trade with each other. In economics, the exchange rate of a country's currency can be divided into the nominal exchange and real exchange rates. The real exchange rate expresses the rate at which we can trade the goods of one country for the goods of another country. The factors that affect the exchange rate of the dollar against the rupiah are supply and demand. The increase in the exchange rate of the dollar against the rupiah has both positive and negative impacts on issuers. This means that the share price of issuers that are positively affected will experience an increase in prices on the stock exchange while the share price of issuers that are negatively affected will experience a decline in prices on the stock exchange (Samsul, 2015).

Definition of Market Efficiency According to Gumanti and Utami (2004) what is meant by the market is the capital market and money market. A market is said to be efficient if no one, both individual investors and institutional investors, will be able to obtain abnormal returns, after adjusting for risk, using existing trading strategies. Prices formed in the market are a reflection of existing information or "stock prices reflect all available information". Another expression states that in an efficient market the prices of assets or securities quickly and completely reflect the available information about these assets or securities (Samsuar \& Akramunnas, 2017). Disclosure of accounting information can give a signal that the company has good prospects (good news) or vice versa a bad signal in the future. If a company wants its shares to be purchased by investors, the company must disclose its financial statements openly and transparently. Information published as an announcement will provide a signal for investors in making investment decisions. If the announcement contains a positive value, it is expected that the market will react when the announcement is received by the market (Rokhlinasari, 2016). The classical theory states that the interest rate is determined by the balance of the demand for investment and the supply of savings. The interest rate is the meeting point between supply and demand for investment. The point of balance is always moving and never at a certain point in the long run. Although this equilibrium point will try to always remain at point $\mathrm{E}$ for a long time. This point will be illustrated through the image below. Where $\mathrm{i}$ is the equilibrium interest rate and $\mathrm{Q}$ is the equilibrium unit quantity supplied and demanded by the market.

According to Mankiw (2006), the Keynesian intersection shows the relationship between national income and interest rates. An increase in the interest rate can cause planned investment to fall and national income to decrease. In the Dictionary of Capital Market and Financial terms, the word "investment" is defined as the investment of money or capital in a company or project to make a profit. Investment can be defined as deferring current consumption to be included in productive assets for a certain period. With the existence of productive assets, delaying current consumption to invest in these productive assets will increase total utility (Muksal, 2016).

According to Sunariyah (2011) Owners of financial assets in the context of investment can be done in two ways, namely direct investment, and indirect investment. Direct investment is the ownership of securities directly intending to obtain profits in the form of capital gains and dividend income. Indirect investment occurs when the securities are owned and traded back by the investment company as an intermediary.

According to the Law of the Republic of Indonesia Number 8 of 1995 concerning the Capital Market, Capital Market is an activity related to the Public Offering and trading of Securities, Public Companies relating to the issued Securities, as well as institutions and professions related to Securities. The capital market of a country has the following functions (Muklis, 2016):

First, as a means of increasing capital for businesses, companies can obtain funds by selling shares to the capital market. Second, income distribution, after a certain time, the shares purchased 
will provide dividends (part of the company's profits) to the buyers (the owners). Next, as a means of increasing production capacity, with additional capital obtained from the capital market, the company's productivity will increase. Then as a means of creating manpower, the existence of the capital market can encourage the emergence and development of other industries that have an impact on the creation of new jobs. It can be as a means of increasing state revenue, any dividends distributed to shareholders will be taxed by the government. Last, it becomes an indicator of the country's economy, the increasing (solid) activity and volume of sales/purchases in the capital market indicates that the business activities of various companies are running well. Vice versa.

The benefits of the capital market according to Muklis (2016) including the number of funds that can be raised is large, the funds can be received at once when the primary market is completed, there are no covenants so that management can be freer in managing funds/companies, the solvency of the company is high so that improve the company's image, the issuer's dependence on banks becomes smaller. Meanwhile, for investors, the capital market has several benefits, including investment value development following economic growth. This increase is reflected in the increase of stock prices, dividends for those who own/hold shares, and floating interest for bondholders.

There are four types of capital markets according to Sunariyah (2011): Primary Market, offering shares made by companies that issue shares (issuers) to investors/investors during the time specified by the party before the shares are traded on the secondary market. Secondary Market, stock trading after going through the process of offering and asking in the primary market. Third Market, a place for transactions of shares or other securities outside the stock exchange. Fourth Market, a form of securities trading between investors without going through a securities broker. In the course of the development of the capital market in Indonesia, there has been progress, as an illustration, that there are at least some developments and progress of the Islamic capital market that should be noted until 2004, including the issuance of 6 (six) Fatwas of the National Sharia Council of the Indonesian Ulema Council (DSN-MUI) related to the capital market industry. The six fatwas in question are No.05/DSN-MUI/IV/2000 concerning the Sale and Purchase of Shares. No.20/DSN-MUI/IX/2000 concerning Guidelines for Investment Implementation for Sharia Mutual Funds. No.32/DSN-MUI/IX/2002 concerning Sharia Bonds. No.33/DSN-MUI/IX/2002 concerning Mudharabah Sharia Bonds. No.40/DSN-MUI/IX/2003 concerning the Capital Market and General Guidelines for the Implementation of Sharia Principles in the Capital Market Sector. No.41/DSN-MUI/III/2004 concerning Sharia Ijarah Bonds.

The fatwas mentioned above regulate sharia principles in the capital market sector which include that security is deemed to have complied with sharia principles if it has obtained a written statement of sharia conformity from the DSN-MUI. The stages that must be passed to obtain a sharia certificate/predicate from DSN-MUI are that the prospective issuer must first present the profit-sharing structure with customers/investors, the structure of the transaction, the form of the agreement such as a trustee agreement, etc. (Sunariyah, 2011).

In the Indonesian Islamic capital market, there is an index called the Jakarta Islamic Index which was launched based on sharia principles on July 3, 2000. JII is a collaboration between the Indonesia Stock Exchange (IDX) and PT Danareksa Investment. According to Oktaviani (2017) determination of stock selection criteria in JII involves the Sharia Supervisory Board of PT Danareksa Investment Management (Sunariyah, 2011).

The purpose of the Jakarta Islamic Index which involves 30 selected stocks is as a benchmark for measuring investment performance in sharia-based stocks. With the existence of JII, it is hoped that it will increase the confidence of investors to develop sharia-compliant investments or to provide opportunities for investors who want to invest following sharia principles. 
The calculation of sharia shares in JII is carried out by the Indonesia Stock Exchange using the index calculation method determined by market capitalization-weighted (Market Capitalization Weighted). This calculation includes adjustments made by changes to the issuer, namely corporate action.

The review is carried out every six months, namely in January and July. The development of the Islamic capital market in Indonesia is generally marked by various indicators, including the increasing number of Islamic capital market players issuing sharia securities other than shares in JII.

Research on JII has been carried out previously in several periods and various methods. One of the previous studies conducted by Muksal (2016) with the population in the study of companies registered at JII 2009-2013 using statistical analysis techniques. The test results show that simultaneously there is an effect of the ROA, DER, and BV variables on changes in stock prices, and partially the ROA variable has a positive and significant effect, the DER and BV variables have no effect. Kennedy (2018), conducted a study that aims to identify determine factors that influence macroeconomic variables, namely inflation, exchange rates, oil prices, and the price index of building materials on changes in stock prices for property sector companies on the Indonesia Stock Exchange (IDX) partially or simultaneously for the period 2008-2015. The results showed that inflation, exchange rates and oil prices had an effect on changes in stock prices. However, the building material price index has no effect on changes in stock prices. The results of the $\mathrm{F}$ test explain that inflation, exchange rates, oil prices, and the building material price index affect changes in the company's property sector stock prices simultaneously.

Research about the effect of inflation and SBI interest rates on stock prices was written by Wardani $\&$ Andarini (2016). The fundamental factors used in this study were the Current Ratio, Return on Assets, Debt Equity Ratio, and Total Asset Turn Over. The sample is 132 firm years of Real Estate and Property Companies Listed on the IDX. The results showed that fundamentals, inflation, and SBI interest rates had a positive effect on stock prices.

Pangestu et al. (2019) in their research aims to determine the effect of macroeconomic indicators with the independent variables of the exchange rate, inflation, interest rates, money supply on the stock index as the dependent variable. The results showed that there was a simultaneous significant effect of the indicator variables of the exchange rate, inflation, interest rates, money supply on the stock index. Partially, the exchange rate and interest rate variables have a significant effect, while the inflation and money supply variables have no significant effect.

Pratama et al. (2019) in their research took the object of the Jakarta Islamic Index (JII) company listed on the IDX for the period 2014-2017. Analysis of the data used is multiple linear regression analysis. Partially Debt to Equity Ratio (DER) does not affect stock prices. Research conducted by Hasanah (2015) using a population of all food and beverage companies listed on the Indonesia Stock Exchange for the period 2011-2015. The sampling in this study used a purposive sampling technique with 12 companies. The analysis technique in this study uses multiple linear regression. The results of his research show that the Return of Assets (ROA) has a positive and significant effect on stock prices. Debt Equity Ratio (DER) has a positive effect on stock prices. The results showed Adjusted R2 of $78.9 \%$ that the contribution of PER, EPS, ROA, and DER to stock prices was $78.9 \%$.

Research from Suselo et al. (2015) aims to examine the effect of fundamental and macroeconomic variables on the stock prices of companies included in the LQ45 index for the period 2010 to 2012. The population in this study was 30 companies that were included in the LQ45 index group. The data analysis method used is multiple linear regression analysis. The results showed that ROA, PBV, and interest rate sensitivity had a significant positive effect on 
stock prices. Exchange rate sensitivity has a significant negative effect on stock prices. DER has no significant effect on stock prices.

Hantono et al. (2019) in their research aims to examine the effect of the Debt to Equity Ratio, Current Ratio, Business Risk, Company Size, and Book Value on Stock Prices in companies in the Basic Industry and Chemical sector. This research is descriptive quantitative. The results showed that simultaneously the Debt Ratio to Equity, Current Ratio, Business Risk, Company Size, and Book Value had a significant effect on stock prices. Partially, the Business Risk variable that uses the ROE ratio has a significant effect on stock prices. While the ratio of debt to equity, the current variable ratio, company size, and book value do not have a significant effect on stock prices.

Research from Putri \& Saryadi (2017) explained that there is a significant ROA effect on stock prices between variable Effect of Return on Assets (ROA), Return on Equity (ROE), Net Profit Margin (NPM), and Earning Per Share (EPS) on Stock Prices. Further, Harahap's research (2016) states that the book value of the company assets of PT. Aneka Tambang (Persero) Tbk. Positive and significantly affects the share price of PT. Indonesian Satellite Corporation (Persero) (INDOSAT) Tbk. The movement of the debt ratio (debt ratio) of PT. Indonesian Satellite Corporation (Persero) (INDOSAT) Tbk. significantly affect the company's stock price negatively. The movement of interest rates significantly affects negatively the stock price at PT. Various Mines. The movement of foreign exchange rates (exchange rate) does not significantly affect the stock price of PT. Aneka Tambang (Persero) Tbk. And PT. Indonesian Satellite Corporation (Persero) (INDOSAT) Tbk.

The research conducted by Junaeni (2017) aims to analyze the effect of the variables Economic Value Added, Return on Assets, Debt to Equity Ratio, and Total Assets Turnover on stock prices of food and beverage companies listed on the Indonesia Stock Exchange for the period 2010 to 2014. Based on the test results t, it can be concluded that partially EVA, ROA, DER, and TATO variables have no significant effect on stock prices because they have a significance value greater than 0.05. Based on the results of the F test, it is concluded that there is a simultaneous (together) significant effect between EVA, ROA, DER, and TATO variables on stock prices.

Another study from Dewi et al. (2018) stated that the Return on Assets (ROA) as measured by the ratio has no effect on stock prices in companies that are members of the Jakarta Islamic Index. Further, research conducted by Hasanah (2017) explained 12 food and beverage companies listed on the Indonesia Stock Exchange from 2011 to 2015 with a purposive sampling technique. The results of her research showed that the Return of Assets (ROA) has a positive and significant effect on stock prices. Debt Equity Ratio (DER) has a positive effect on stock prices. In line with other studies, ROA has a significant effect on stock prices (Hamrita \& Trifi, 2011; Rahman \& Suherman, 2017). The greater the ROA of the company, the greater the level of profit achieved by the company (positive correlation).

Based on the discussion of various theories and previous research, the following hypotheses: It is suspected that the book value has a positive influence on the stock price company in JII. It is suspected that the debt-equity ratio has a negative effect on the prices of company shares in JII. It is suspected that the return of assets has a positive effect on the prices of company shares in JII. 4.It is suspected that interest rates have an influence on stock prices company in JII. It is suspected that the exchange rate has a negative effect on stock prices company in JII.

Based on the differences in research results and literature review, this research is the point at the development of Islamic Shares (JII). The dependent variable is the company's stock price in JII and the independent variables are book value, DER, ROA, interest rates, and exchange rates. 


\section{Research Method}

This study used secondary data, sourced from existing studies and reports from certain agencies, such as Bank Indonesia or other publications. Secondary data includes a combination of time series data with a period of 2014-2020 and cross-section data covering 30 companies listed in the Jakarta Islamic Index (JII) which produces 210 samples. In general, the data in this study were obtained from the Indonesia Stock Exchange, Bank Indonesia, and the Financial Services Authority. For stock price variables, BV, DER, and ROA were obtained from the official website of the Indonesia Stock Exchange, the SB and KURS variables were sourced from the official website of Bank Indonesia, while the data on Capitalization of the Islamic stock market was wrong from the official website of the Financial Services Authority. Other information comes from other literature studies in the form of scientific journals and textbooks. This study uses stock prices as the dependent variable. This study using the price of a stock with the share price represented by the closing price at the end of the year. This is because the stock price at the end of the year is considered to represent fluctuations in share prices that occur in one period (measured in rupiah units).

This study will examine the factors that influence stock prices in companies listed on JII using panel data regression analysis, the formulation of the estimator model is:

$$
\operatorname{Ln}(\text { Price }) \text { it }=0+\beta 1 \operatorname{Ln}(\mathrm{BV}) \text { it }+2 \operatorname{Ln}(\mathrm{DER}) \text { it }+\beta 3(\mathrm{ROA}) \mathrm{it}+4(\mathrm{SB}) \mathrm{it}+\beta 5 \mathrm{Ln}(\mathrm{KURS}) \text { it }+ \text { et }
$$

where $\mathrm{Ln}$ is the natural logarithm, Price is the stock price, BV is the price of the company's book value, DER is the ratio of total debt to equity, ROA is economic profitability, SB is the interest rate, and KURS is dollar exchange rate against rupiah. In addition, there are coefficients like $\beta_{0}$ (constant), $\beta_{1}$ until $\beta_{5}$ (independent regression coefficient) and subscript $i$ or $t$ (observation to $\mathrm{i}$, and year to $\mathrm{t}$ ).

The estimation of the econometric model of the panel data above then need to process toward thia following steps:

1.Estimating the PLS, FEM, and REM panel data models.

2. Test the panel data model selection using the Chow Test, Langrange Multiplier Test and Hausman Test.

3. Test the goodness of the model on the selected panel data model and the R-Square interpretation.

4. Test the validity of the effect.

According to Juanda (2012) panel data is data obtained through cross-section data that is observed at different times and repeatedly on the same object. In other words, panel data is a combination of cross-section data and time-series data.

While the independent variables consist of:

a. Book Value (BV)

Book value per share shows the net assets owned by shareholders by owning per share (Sunariyah, 2011). Where is the formula for calculating the book value as shown

$$
\mathrm{BV}=\frac{\text { Total equity }}{\text { The number of shares outstanding }}
$$

b. Debt to Equity Ratio (DER)

DER is a comparison between loan/debt funds compared to capital to develop a company (Samsuar \& Akramunnas, 2017). 
c. Return on Asset (ROA)

$$
\text { DER }=\frac{\text { Total liabilities }}{\text { Equity }}
$$

Return on Assets (ROA) or what is often translated into Indonesian as economic profitability is a ratio that measures the company's ability to generate profits in the past (Z. Hasanah et al., 2017).

d. Interest rate (SB)

$$
\text { ROA }=\frac{\text { Profit before tax }}{\text { Total assets }} \times 100 \%
$$

According to Sukirno (2004), the interest rate is the percentage of income received by creditors from the debtor during a certain time interval.

e. Exchange rate (KURS)

The exchange rate or foreign currency exchange rate shows the price or value of one country's currency expressed in terms of the currency of another country (Sukirno, 2013). So, the exchange rate is the price that must be paid by the currency of a country to obtain the currency of another country, the price paid is called the exchange rate.

Panel data regression is a regression technique that combines time series data with cross-section. According to Juanda (2012) panel data is data obtained through cross-section data that is observed at different times and repeatedly on the same object. In other words, panel data is a combination of cross-section data and time-series data.

Afterward, the panel data econometric model estimation is formed by the following step (1) estimating the PLS, FEM, and REM panel data models. Selection of Pooled Least Square (PLS) with Fixed Effect Model (FEM), the likelihood ratio test (Chow test) is used, which is used to select the panel data technique with PLS or FEM. Then test the hypothesis by:

$\mathrm{H}_{0}$ : Common Effect Model

$\mathrm{H}_{1}$ : Fixed Effect Model

$\mathrm{H}_{0}$ is rejected if the Prob cross-section-F and cross-section Chi-square $<0.05$ at a significant level of $5 \%$. If $\mathrm{H}_{0}$ is rejected, then FEM will be selected for further processing. Selection of Pooled Least Square (PLS) with Random Effect Model (REM) use Lagrange Multiplier (LM). LM is a test to determine whether the random effect model or the common effect model is more appropriate to use. This random effect significance test was developed by Breusch Pagan.

The hypotheses used are:

$\mathrm{H}_{0}$ : The model follows the common effect

$\mathrm{H}_{1}$ The model follows the random effect

To determine the decision, it can be seen from the Breusch-Pagan probability value. If the value is above 0.05 or not significant, then $\mathrm{H} 0$ is accepted and if it is below 0.05 or significant then $\mathrm{H} 0$ is rejected and $\mathrm{H} 1$ is accepted.

Panel data model selection test using Chow Test, Lagrange Multiplier Test, and Hausman Test, (3) test the goodness of the model on the selected panel data model and the R-Square interpretation. Coefficient of determination (R2) essentially measures how far the model's ability to explain variations in the dependent variable is. The value of $\mathrm{R} 2$ that is close to one means that the independent variables provide almost all the information needed to predict the variation of the dependent variable. The value of the coefficient of determination is between 0 and 1 . A small value of R2 means that the ability of the independent variables to explain the variation of the dependent variable is very limited. A value close to 1 (one) means that the independent variables provide almost all the information needed to predict the variation of the dependent variable.

The last step for the test is the validity of the effect. The effect validity test examines the significance of the effect of the independent variables individually. The effect validity test is the $t$ test. $\mathrm{H} 0 \mathrm{t}$ test is $\mathrm{i}=0$, the independent variable to $\mathrm{i}$ has no significant effect; and its HA $\mathrm{i} 0$, the 
independent variable has a significant effect. $\mathrm{HO}$ will be accepted if the p-value, probability, or empirical statistical significance $\mathrm{t}>\alpha$; $\mathrm{H} 0$ will be rejected if the $\mathrm{p}$-value, probability, or empirical statistical significance $\mathrm{t} \leq \alpha$. The model exists if all independent variables simultaneously influence the dependent variable (regression coefficient is not simultaneously zero). The model existence test is the F test. In this study, the hypothesis formulation of the model existence test is $\mathrm{H} 0: \mathrm{H}_{0}$ : $\beta_{1}=\beta_{2}=\beta_{3}=\beta_{4}=0$ the regression coefficient is simultaneously zero or the model does not exist; $\mathrm{H}_{1}$ : $\beta_{1} \neq 0\left|\beta_{2} \neq 0\right| \beta_{3} \neq 0 \mid \beta_{4} \neq 0$, the regression coefficient is not simultaneously zero or the model exists. $\mathrm{H} 0$ will be accepted if the $\mathrm{p}$-value, probability, or statistical empirical significance $\mathrm{F}>\alpha$.; $\mathrm{H} 0$ will be rejected if the $\mathrm{p}$-value, probability, or empirical statistical significance is $\mathrm{F} \leq \alpha$.

\section{Results and Discussions}

The average price sharia shares of companies listed on the Jakarta Islamic Index (JII) in 2014-2018 very varied, ranging from Rp 7000.00 per share. The lowest average price is found in the company Waskita Beton Precast Tbk. (WSBP) amount to Rp.430.00 because this company is a company that relatively new in offering shares to general investors in 2016. While companies that have an average value of the highest share was Unilever Indonesia Tbk., which was Rp.42,205.00 because of the shares of Unilever Indonesia Tbk. share large-capitalization which is quite active and liquid in the stock market, in addition to the Unilever Indonesia company has a pretty good reputation in the eyes of the public.

Companies that have the lowest average book value of the year 2014-2018 are Waskita Beton Precast, which is Rp. 196.10 per sheet. This is because this company has only offered shares in 2016, while the company that has the highest average book value from 2014-2018 is United Tractors Tbk. (UNTR) which is Rp 11928.06 per share because this company experienced an increase in the number of equities caused by the increasing demand for heavy equipment as well as commercial vehicles fueled by increased development infrastructure and business centers in Java and Sumatra. The average book value of companies listed in JII is around Rp 2500.00 per sheet.

The companies listed in JII have an average debt-equity ratio of 1.1 times. An average of the lowest corporate debt-equity ratio in 2014-2018 is company Indocement Tuggal Prakasa Tbk. (INTP) which is 0.17 times. This is because there is an increase in demand for cement which makes cash internal company is able to provide budget needs without debt. While the highest is the company Matahari Department Store Tbk (LPPF)with an average debt-equity ratio of 4.93 times this is due to a decrease in sales and increased outlet cost pressure as a result of competition sales with an online store.

The average ROA value of JII companies is around 9.50\%. With an average ROA of the lowest $-1.14 \%$, namely in the company Aneka Tambang Persero Tbk. (ANTM). This is because of the enactment of the mineral export ban policy on 12 January 2014 which made the Aneka Tambang company Persero as an exporting company of nickel ore suffered significant losses make the ROA of the company's shares decrease. Then the highest average ROA in Unilever Indonesia companies Tbk. (UNVR) of $39.85 \%$ because the company Unilever Indonesia Tbk. have a competitive advantage in the consumer goods industry become a big leader in the consumer goods industry market in Indonesia so that this company has good financial performance and becomes one of the company's shares that are considered good on the Indonesian stock exchange.

In 2014 the interest rate reached $7.67 \%$, then in 2015 decreased by $7.63 \%$. From 2016 to 2017 the rate of interest rates again decreased from 5.84\% to $4.38 \%$ this was due to BI's view that the realization and forecast of inflation in 2017 and 2018 are within the set target range. Then in 
2018 interest rates have increased by 5\%. The exchange rate of the rupiah against the dollar experienced a fluctuating increase. In 2014 the exchange rate showed a number amounting to Rp. $12,440.00 /$ US\$. Then in 2015, the exchange rate experienced an increase to reach the figure of Rp. $13,795.00$, this is caused by the continuation of the prolonged crisis in Greece, US economic recovery, dynamics politics in the government transition period (Mns, 2018). From 2016 until 2017 the exchange rate ranges from Rp. 13,500 the highest in 2018 which was Rp. 14,710.00 due to a deficit current account, escalation of the US-China trade war, emerging market crisis (Turkey, Iran, Argentina, and South Africa), US economy strengthened.

This study observed the factors that influence share prices in companies listed in JII using panel data regression analysis tools. After determining the regression equation model, panel data regression was carried out using three methods, Common Effect Model (CEM), Fixed Effect Model (FEM), and Random Effect Model (REM). The regression results of the three models can be seen in Table 1 below:

Table 1. Panel Data Regression Results

\begin{tabular}{llll}
\hline & \multirow{2}{*}{ Variable } & \multicolumn{3}{c}{ Coefficient } \\
& CEM & FEM & REM \\
\hline C & -1.036584 & 3.278651 & 1.597240 \\
LOG(BV) & 0.553308 & 0.002212 & 0.174489 \\
LOG(DER) & 0.078714 & 0.029847 & 0.072693 \\
ROA & 0.069427 & 0.049480 & 0.065154 \\
SB & -0.045220 & -0.055934 & -0.066275 \\
LOG(KURS) & 0.498624 & 0.481987 & 0.521125 \\
R $^{2}$ & 0.550128 & 0.928693 & 0.229815 \\
Adj R & 0.538767 & 0.914348 & 0.210366 \\
F-Statistik & 48.42497 & 64.73656 & 11.81621 \\
Prob F-Statistik & 0.000000 & 0.000000 & 0.000000 \\
\hline
\end{tabular}

To choose the best model between the Common Effect, Fixed Effect, and Random Effect Models, the Chow test and Hausman test was carried out. Chow test is a test used to select the best panel data regression model between Common Effect (CEM) and Fixed Effect (FEM). The results of the chow test processing are as follows:

Table 2. Panel Data Estimation Results With Chow Test

\begin{tabular}{|c|c|c|}
\hline Effect Test & Statistics d.f & Prob \\
\hline Cross-section F & 23.943172 & $(29,169)$ \\
\hline
\end{tabular}

Hypothesis Formula

$\mathrm{H}_{0}$ : Common Effect Model is better than Fixed Effect Model

$\mathrm{H}_{\mathrm{a}}$ : Fixed Effect Model is better than Common Effect Model

b. Determining the level of significance

Significance $(\alpha)=0.05$

c. Testing Criteria

$\mathrm{H} 0$ is accepted if $\mathrm{p}$-value $>0.05$

Ha is accepted if $p$-value $\leq 0.05$

d. Conclusion

The p-value or F-test probability is $0.0000<0.05$. So, Ha is accepted, so the model follows the Fixed Effect Model (FEM). 
Hausman test is a test used to select the best panel data regression model between Fixed Effect Model (FEM) and Random Effect Model (REM). The results of the Hausman test are as follows:

Table 3. Panel Data Estimation Results With Hausman Test

\begin{tabular}{lllrl}
\hline Test Summary & Chi-Sq. Statistics & Chi-Sq. d.f. & Prob. \\
\hline Cross-section random & 36.996031 & 5 & 0.0000 & \\
\hline
\end{tabular}

a. Hypothesis Formula

$\mathrm{H}_{0}$ : Random Effect Model is better than Fixed Effect Model

Ha : Fixed Effect Model is better than Random Effect Model

b. Determining the level of significance

Significance $(\alpha)=0.05$

c. Test Criteria

$\mathrm{H} 0$ is accepted if $\mathrm{p}$-value $>0.05$

$\mathrm{Ha}$ is accepted if the p-value 0.05

d. Conclusion

The p-value or probability of Chi-square or random cross-section is 0.00000 .05 . So, Ha is rejected. The model follows the Fixed Effect Model (FEM).

Based on the two best model selection tests, specifically, the Chow test and the Hausman test, the Fixed Effect Model (FEM) and Random Effect Model (REM) were selected as the best models in interpreting panel data regression. Whose estimator model formulations formed :

$$
\operatorname{Ln}(\text { Price }) \text { it }=\beta 0+\beta 1 \operatorname{Ln}(\mathrm{BV}) \text { it }+\beta 2 \operatorname{Ln}(\mathrm{DER}) \text { it }+\beta 3(\mathrm{ROA}) \text { it }+\beta 4(\mathrm{SB}) \mathrm{it}+\beta 5 \mathrm{Ln}(\mathrm{KURS}) \text { it }+ \text { et }
$$

where $\mathrm{Ln}$ is the natural logarithm, Price is the stock price, BV is the price of the company's book value, DER is the ratio of total debt to equity, ROA is economic profitability, SB is the interest rate, and KURS is dollar exchange rate against rupiah. In addition, there are coefficients like $\beta_{0}$ (constant), $\beta_{1}$ until $\beta_{5}$ (independent regression coefficient) and subscript $i$ or $t$ (observation to $i$, and year to $t$ ).

The summary of the regression results for the selected models can be seen in Table 4 .

Table 4. Summary of Selected Model Data Panel Regression Results

\begin{tabular}{lllll}
\hline Variable & $\begin{array}{l}\text { Regression } \\
\text { Coefficient }\end{array}$ & $\begin{array}{l}\text { Standard } \\
\text { Error }\end{array}$ & T & Sig. \\
\hline C & 3.278651 & 5.076301 & 0.645874 & 0.5192 \\
LOG(BV) & 0.002212 & 0.039183 & 0.056459 & 0.9550 \\
LOG(DER) & 0.029847 & 0.090135 & 0.331133 & 0.7410 \\
ROA & 0.049480 & 0.006623 & 7.470766 & 0.0000 \\
SB & -0.055934 & 0.015312 & -3.653020 & 0.0003 \\
LOG(KURS) & 0.481987 & 0.534428 & 0.901875 & 0.3684 \\
R-squared & 0.928693 & & & \\
Adjusted R-squared & 0.914348 & & & \\
F-statistic & 64.73656 & & & \\
Prob(F-statistic) & 0.000000 & & &
\end{tabular}


Based on Table 4, the panel data regression equation is obtained with Fixed Effect Model. This model uses the LnPrice variable as the dependent variable, and LnBV, LnDER, ROA, SB, and LnKURS as independent variables.

The panel data regression equation with the selected model can be seen in Table 5 below:

Table 5. Regression Equations with Fixed Effect Model

\begin{tabular}{|c|}
\hline $\operatorname{Ln}($ Price $)$ it $=3.278651+0.002212 \operatorname{Ln}(B V) i t+0.029847 \operatorname{Ln}(D E R) i t+0.049480($ ROA $) i t$ \\
\hline $\begin{array}{cl}-0.055934(S B) i t+ & 0.481987 \operatorname{Ln}(K U R S) i t+e i t \\
(0.0003)^{*} & (0.3648)\end{array}$ \\
\hline
\end{tabular}

Based on the results of the validity test, the independent variables have a significant effect, namely Return on Asset and Exchange Rate. The Return on Assets has a t-value of 0.0000 while the Exchange rate has a t-value of 0.0003 . The ROA variable has a regression coefficient of 0.049480. The econometric model between the ROA and LnPrice variables is logarithmic-linear. This means that if ROA increases by one percent, then LnPrice will increase by 4.9480 percent. Conversely, if ROA decreases by one percent, then LnPrice will decrease by 4.9480 percent. This is following Hamrita \& Trifi (2011), Rahman (2017) and Muksal (2016), which states that ROA has a significant effect on stock prices. The greater the ROA of the company, the greater the level of profit achieved by the company (positive correlation). However, this result contradicts the research conducted by Dewi (2018) which states that the Return on Assets (ROA) as measured by the ratio has no effect on stock prices in companies that are members of the Jakarta Islamic Index.

The SB variable has a regression coefficient of 0.055934 . The econometric model between the SB variable and LnPrice is logarithmic-linear. This means that if SB increases by one percent, the LnPrice will be decreased by 5.5934 percent. Conversely, if SB decreased by one percent, then LnPrice would increase by 5.5934 percent. This is in contrast to the research of Ash-Shidiq \& Setiawan (2015) which found that the interest rate did not have a significant effect on JII.

Meanwhile, BV, DER, and KURS variables do not have a significant effect on stock prices because the t-value is less than 0.05. This is by Muksal (2016), with the population in the research of companies listed in JII 2009-2013, this study shows that simultaneously there is an influence from the variables ROA, DER, and BV on stock price changes, and partially the ROA variable has a positive effect and significantly, the variables DER and BV have no effect. In contrast to this study, Kennedy (2018) found that the exchange rate (KURS) has a significant effect on stock prices. The coefficient of determination (R2) is used to measure the ability of the model to explain the variation in the dependent variable. The estimation results show that the $\mathrm{R} 2$ value is 0.928693 which can be interpreted as $92.8693 \%$, meaning that $92.8693 \%$ of the LnPrice variation can be explained by LnBV, LnDER, ROA, SB, and LnKURS, and the remaining $7.1307 \%$ is explained by other variables not included in the model.

Based on the results of the test analysis as has been done using panel data regression analysis using the selected model is the fixed effect model (FEM). Interpretation of each coefficient value of the independent variable and the dependent variable can be described as follows:

Book value has a negative and insignificant effect on share prices of 30 companies in JII. This happens because the average price the shares of companies in JII are overvalued or lower (undervalued) compared to the book value of the company's shares. So, if the book value increases, the share price is likely to increase will experience a decline to approach the book value of the stock at the company. The results of this study are supported by research that conducted by 
Hantono, et al. (2019) who stated that Book Value on stock prices does not have a significant effect, meaning that the value of the company's book is usually a benchmark for investors in buying something shares, but in this study, the book value of the company do not affect a stock price so the book value cannot be used as a benchmark in determining a share price.

The debt-equity ratio has a positive and significant impact on the share price of 30 companies in JII. This happened because the company with A high Debt to Equity Ratio indicates that it is getting bigger the proportion of debt owned by the company, the company will be more dare to seek funding from outside the company so that the company will focus on settling obligations (paying debts) by offering the company's stock price at a higher price. Then on the side of investors, it seems that debt is considered something reasonable because growing companies need debt as additional funds for the company. The amount of the company's operating funds of course it cannot be financed by capital from the company itself. The results of this research support the research conducted by Wardani, et al (2016) state that there are different considerations of some investors in viewing DER. By some investors, DER is viewed as the amount of the company's responsibility to third parties, namely creditors who provide loans to the company. So that it gets bigger DER value increases the company's liability. However, it seems that some investors view that companies that growing up require debt as additional funds to fulfill funding for growing companies.

Return of assets has a positive and significant effect on prices stocks. This happens because of the high ROA, which can indicate that the performance of the company is good because it can return high dividends to investors. High dividends offered to companies can attract investors to invest in the company so that this will encourage the company to increase its share price. The results of this study support research from Hasanah, et al (2016) in their research, the value of ROA has a significant effect on stock prices in food and beverage companies and obtained highvalue ROA. Then the better the company's performance and this indicates the company is able to pay high dividends highly paid by the company makes investors interested in buying shares of food and beverage companies. Thus, the stock price will tend to be high.

Interest rates have a negative and significant effect on the stock prices of 30 companies in JII. This happens because the interest rates increased resulting in an increase in the company's expenses in pay credit to the bank, this can reduce the level of profit dividend return to investors so that the stock price of the company experienced a decline as a result of reduced interest investors to invest their capital. This research supports research conducted by Pangestu, et al. (2019) with results that show that high-interest rates will make investors generally more choose to invest in the form of letters or save in a bank in form of deposits that can ultimately reduce the passion for development businesses because it results in high-interest rates for other banks. Thus, causing the company's stock price to decline.

The exchange rate has a positive and insignificant effect, this happens because if the rupiah strengthens against the US dollar then this will increase stock prices of companies that use foreign raw materials country as a result of rising production costs the company at JII does not use raw materials from abroad make the exchange rate has no significant effect on stock prices. This study supports the research of Kennedy et al (2018) that the value of the exchange rate also has an influence, strong or weak, on the rupiah exchange rate. The US Dollar affects changes in the company's stock price fluctuates, then the dollar value of imported goods purchased also fluctuates.

If the exchange rate falls or the rupiah depreciates, it will have a negative impact on companies whose raw materials are imported from outside. When the exchange rate falls, the price the stock will also decrease which will cause the company to be unattractive for investors. 
Meanwhile, oil prices are often in the spotlight of investors because it will have an impact on other prices. This study also examines which companies the high and low share prices. The result shows at Table 6 that as many as 30 companies are listed on the Jakarta Islamic Index (JII) for the period December 2020 to May 2021.

Table 6. Summary of Selected Model Data Panel Regression Results

\begin{tabular}{|c|c|c|c|c|c|c|c|c|c|}
\hline No. & Code & Effect & C FEM & $\begin{array}{l}\text { Effect C } \\
\text { FEM }\end{array}$ & No & Code & Effect & C FEM & $\begin{array}{l}\text { Effect C } \\
\text { FEM }\end{array}$ \\
\hline 1 & ADRO & -0.72896 & 3.278651 & 2.549691 & 16 & MDKA & -0.090144 & 3.278651 & 3.188507 \\
\hline 2 & AKRA & 0.488483 & 3.278651 & 3.767134 & 17 & MIKA & -0.55208 & 3.278651 & 2.726571 \\
\hline 3 & ANTM & -0.745761 & 3.278651 & 2.53289 & 18 & $\mathrm{MNCN}$ & -0.856233 & 3.278651 & 2.422418 \\
\hline 4 & BRPT & -1.230495 & 3.278651 & 2.048156 & 19 & PGAS & -0.166759 & 3.278651 & 3.111892 \\
\hline 5 & BTPS & 0.062207 & 3.278651 & 3.340858 & 20 & PTBA & -0.530177 & 3.278651 & 2.748474 \\
\hline 6 & CPIN & 0.251503 & 3.278651 & 3.530154 & 21 & РTPP & -0.146815 & 3.278651 & 3.131836 \\
\hline 7 & EXCL & 0.320586 & 3.278651 & 3.599237 & 22 & PWON & -1.757945 & 3.278651 & 1.520706 \\
\hline 8 & ICBP & 0.990801 & 3.278651 & 4.269452 & 23 & SCMA & -0.993576 & 3.278651 & 2.285075 \\
\hline 9 & INCO & 0.346396 & 3.278651 & 3.625047 & 24 & SMGR & 1.313378 & 3.278651 & 4.592029 \\
\hline 10 & INDF & 1.025829 & 3.278651 & 4.30448 & 25 & TKIM & 4.57E-05 & 3.278651 & 3.2786967 \\
\hline 11 & INKP & 0.219691 & 3.278651 & 3.498342 & 26 & TLKM & -0.066222 & 3.278651 & 3.212429 \\
\hline 12 & INTP & 1.758447 & 3.278651 & 5.037098 & 27 & TPIA & 0.4127 & 3.278651 & 3.691351 \\
\hline 13 & JPFA & -0.75134 & 3.278651 & 2.527311 & 28 & UNTR & 2.038756 & 3.278651 & 5.317407 \\
\hline 14 & KAEF & -0.221251 & 3.278651 & 3.0574 & 29 & UNVR & 0.720588 & 3.278651 & 3.999239 \\
\hline 15 & KLBF & -0.883713 & 3.278651 & 2.394938 & 30 & WIKA & -0.28414 & 3.278651 & 2.994511 \\
\hline
\end{tabular}

The company with the first highest share price is United Tractors Tbk. which has a share price of 5.317407 percent. Second place is Indocement Tunggal Prakarsa Tbk. with a share price of 5.037098 percent. In the third position is Semen Indonesia (Persero) Tbk. with a share price of 4.592029 percent. The three companies with the lowest share prices are Surya Citra Media Tbk. by 2.285075 percent, Barito Pacific Tbk. by 2.048156 percent, and Pakuwon Jati Tbk. by 1.520706 percent.

\section{Conclusions}

The development of the capital market is closely related to the investment condition of a country which also reflects the country's economic growth. Furthermore, the increase in stock prices in the capital market can reflect the economic conditions of a country. JII is a capital market index that reflects the increase in the price of halal shares in Indonesia. JII is a performance measure in choosing a halal stock portfolio, the Jakarta Islamic Index which involves 30 selected stocks, namely as a benchmark for measuring investment performance in sharia-based stocks. It can be concluded that Book Value (LnBV), Debt Equity Ratio (LnDER), and Exchange Rate (LnKURS) do not have a significant effect on the Stock Price (LnPrice). However, book value (LnBV), Debt Equity Ratio (LnDER), Return on Assets (ROA), Interest Rate (SB), and Exchange Rate (LnKURS) simultaneously have a significant effect on stock prices (LnPrice). Simultaneously, these variables affect the stock price of $92.8693 \%$, while the rest is influenced by other variables outside the regression model. Further researchers advised to update the development of the Jakarta Islamic Index, in which there are changes in the company every certain period, so research needs to be updated continuously for the validity of the research. Researchers 
also expected to increase the number of samples in the form of the latest research year, where this will add to the quality of the research to be carried out.

Suggestions that can be made based on the results of this research are potential to investors who want to invest in stocks, they should more consider the DER, ROA, and Interest Rate factors because these factors have been shown to have a significant effect on share prices of 30 companies in JII from 2014 to 2018 . The government is expected to maintain the stability of the exchange rate and interest rates to increase the interest of investors to invest in companies, so that company can increase its productivity. Thus, the country's economy will also increase. For further researchers who will research with the same topic by including other independent variables, such as Price Earnings Ratio, Return on Equity, Return on Investment, and other factors that affect stock prices, considering the $\mathrm{R} 2$ in this study was $90.5 \%$.

\section{References}

Ash-Shidiq, H., \& Setiawan, A. B. (2015). Analisis Pengaruh Suku Bunga SBI, Uang Beredar, Inflasi Dan Nilai Tukar Terhadap Indeks Harga Saham Jakarta Islamic Index (JII) Periode 2009-2014. Jurnal Ekonomi Dan Perbankan Syariah, 3(2), 25-46.

Dewi, A. K., Purnomo, H., \& Murniati, W. (2018). Pengaruh Return On Assets (ROA), Return On Equity (ROE) dan Economic Value Added (EVA) Terhadap Harga Saham Perusahaan Yang Tergabung Dalam Jakarta Islamic Index Periode 2014 - 2016. Jurnal Riset Akuntansi, 1(1), 44-48. https://docplayer.info/208886210-Anggita-kumala-dewi-1-hari-purnomo-2wahyuning-murniati-3-sekolah-tinggi-ilmu-ekonomi-widya-gama-lumajang.html

Gujarati, D. N. (2012). Dasar-dasar Ekonometrika, Terjemahan Mangunsong. RC (5th Ed.). Jakarta: Salemba Empat.

Gumanti, T. A., \& Utami, E. S. (2004). Bentuk Pasar Efisiensi dan Pengujiannya. Jurnal Akuntansi Dan Keuangan, 4(1), pp-54.

Hamrita, M. E., \& Trifi, A. (2011). The relationship between interest rate, exchange rate and stock price: A wavelet analysis. International Journal of Economics and Financial Issues, 1(4), 220.

Hantono, H., Sari, I. R., Chiquita, C., Levina, L., Gloriana, M., \& Sabaryanti, S. (2019). Pengaruh Debt To Equity Ratio, Current Ratio, Business Risk, Firm Size, Book Value Terhadap Harga Saham (Studi Kasus Pada Sektor Industri Dasar dan Kimia). Jurnal Ilmiah ESAI, 13(2), 8293.

Harahap, D. (2016). Analisis faktor-faktor yang mempengaruhi harga saham Jakarta Islamic Index (JII). Journal Analytica Islamica, 5(2), 342-367.

Hasanah, U. (2015). Analisis Profitability Ratio dan Market Valuation Ratio Terhadap Harga Saham Studi Pada Perusahaan Industri Manufaktur (Food And Beverage) yang Terdaftar di Bursa Efek Indonesia Tahun 2008-2013. University of Muhammadiyah Malang.

Hasanah, Z., Wahono, B., \& Salim, M. A. (2017). Pengaruh Price Earning Ratio, Earning Per Share, Return On Asset, Debt To Equity terhadap Harga Saham Perusahaan Food and Beverages yang Terdaftar di BEI Tahun 2011-2015. E-Jurnal Riset Manajemen.

Juanda, B. (2012). Junaidi. 2012. Ekonometrika Deret Waktu: Teori dan Aplikasi. IPB Press.

Junaeni, I. (2017). Pengaruh EVA, ROA, DER dan TATO terhadap Harga Saham pada Perusahaan Makanan dan Minuman di BEI. Owner: Riset Dan Jurnal Akuntansi, 1(2), 32-47.

Kennedy, P. S. J., \& Hayrani, R. (2018). Pengaruh Faktor-Faktor Ekonomi Makro: Inflasi, Kurs, Harga Minyak, Dan Harga Bahan Bangunan Terhadap Harga Saham Perusahaan Properti Di 
BEI. Jurnal Mitra Manajemen, 2(1), 1-12.

Kurniawan, A. (2016). Pengaruh Produk Domestik Bruto (PDB) Terhadap Harga Saham Jakarta Islamic Index (JII) di Indonesia Periode Tahun 2006-2013. UIN Raden Fatah Palembang.

Mankiw. (2006). Makroekonomi (6th ed.). Salemba Empat.

Muklis, F. (2016). Perkembangan dan Tantangan Pasar Modal Indonesia. Al-Masraf: Jurnal Lembaga Keuangan Dan Perbankan, 1(1), 65-76.

Muksal. (2016). Analisis Faktor-faktor Yang Mempengaruhi Harga Saham Syariah (Studi Pada Pasar Sekunder Jakarta Islamic Index (JII) Tahun 2009-2013). Jurnal Akad, 1(1).

Nachrowi, D. N., \& Usman, H. (2006). Ekonometrika. Jakarta: LPFEUI.

Oktaviani, R. F. (2017). Index harga saham Islamic internasional terhadap Jakarta Islamic index. Jurnal Ekonomika Dan Manajemen, 6(1), 1-15.

Pangestu, R. D., Husaini, A., \& Sulamsiyati, S. (2019). Pengaruh Indikator Makroekonomi Terhadap Indeks Saham (Studi pada Jakarta Islamic Index, Periode 2014-2018). Jurnal Administrasi Bisnis, 73(2), 143-152.

Prastowo, N. J. (2008). Dampak BI Rate Terhadap Pasar Keuangan: Mengukur Signifikansi Respon Instrumen Pasar Keuangan Terhadap Kebijakan Moneter. Working Paper.

Pratama, C. A., Azizah, D. F., \& Nurlaily, F. (2019). Pengaruh Return On Equity (ROE), Earning Per Share (EPS), Current Ratio (CR) Dan Debt To Equity Ratio (DER) Terhadap Harga Saham (Studi pada Perusahaan Jakarta Islamic Index yang Terdaftar di Bursa Efek Indonesia Tahun 2014-2017). Jurnal Administrasi Bisnis, 66(1), 10-17.

Putri, N. K. A., \& Saryadi, S. (2017). Pengaruh Return On Assets (ROA), Return On Equity (ROE), Net Profit Margin (NPM), Dan Earning Per Share (EPS) Terhadap Harga Saham. Jurnal Ilmu Administrasi Bisnis, 6(4), 124-135.

Rahman, R., \& Suherman, M. (2017). Analisis Harga Saham Melalui Peningkatan Kinerja Keuangan: Studi Pada Perusahaan Yang Terdaftar Di Jakarta Islamic Index. JURNAL AKUNTANSI, 12(2), 135-152.

Rimbani, R. P. (2016). Analisis pengaruh roe, eps, pbv, der, dan npm terhadap harga saham pada perusahaan real estate dan property di bursa efek indonesia (bei) periode 2011-2013. Jurnal Bisnis Dan Manajemen, 53(12).

Rokhlinasari, S. (2016). Teori-teori dalam Pengungkapan Informasi Corporate Social Responbility Perbankan. Al-Amwal: Jurnal Ekonomi Dan Perbankan Syari'ah, 7(1).

Samsuar, T., \& Akramunnas, A. (2017). Pengaruh Faktor Fundamental dan Teknikal terhadap Harga Saham Industri Perhotelan yang Terdaftar di Bursa Efek Indonesia. Al-Mashrafiyah: Jurnal Ekonomi, Keuangan, Dan Perbankan Syariah, 1(1).

Samsul, M. (2015). Pasar Modal dan Manajemen Portofolio Edisi 2. Erlangga. Jakarta.

Sukirno, S. (2004). Makro ekonomi teori pengantar edisi ketiga. Jakarta: Raja Grafindo Persada. Sunariyah. (2011). Pengantar Pengetahuan Pasar Modal (6th ed.). UPP AMPYKPN.

Suselo, D., Djazuli, A., \& Indrawati, N. K. (2015). Pengaruh Variabel Fundamental dan Makro Ekonomi terhadap Harga saham (Studi pada perusahaan yang masuk dalam Indeks LQ45). Jurnal Aplikasi Manajemen, 13(1), 104-116.

Wardani, D. K., \& Andarini, D. F. T. (2016). Pengaruh Kondisi Fundamental, Inflasi, Dan Suku Bunga Sertifikat Bank Indonesia Terhadap Harga Saham (Study Kasus Pada Perusahaan Real Estate Dan Property Yang Terdaftar Di Bursa Efek Indonesia Tahun 2010-2013). Jurnal Akuntansi, 4(2), 77-90. 